九州大学学術情報リポジトリ

Kyushu University Institutional Repository

\title{
Variation of Self-incompatibility in Camellia japonica L. Cultivars
}

Ozaki, Yukio

Laboratory of Horticultural Science, Division of Agricultural Botany, Department of Plant

Resources, Faculty of Agriculture, Kyushu University

\section{Kanda, Motoko}

Laboratory of Horticultural Science, Division of Agricultural Botany, Department of Plant Resources, Faculty of Agriculture, Kyushu University

Mi yaj ima, Ikuo

Laboratory of Horticultural Science, Division of Agricultural Botany, Department of Plant Resources, Faculty of Agriculture, Kyushu University

Okubo, Hiroshi

Laboratory of Horticultural Science, Division of Agricultural Botany, Department of Plant Resources, Faculty of Agriculture, Kyushu University

https://doi.org/10.5109/4493

出版情報：九州大学大学院農学研究院紀要. 47 (2)，pp. 251-255，2003-02-01. Faculty of Agriculture, Kyushu University

バージョン：

権利関係: 


\title{
Variation of Self-incompatibility in Camellia japonica L. Cultivars
}

\author{
Yukio OZAKI', Motoko KANDA*, Ikuo MIYAJIMA \\ and Hiroshi OKUBO
}

\author{
Laboratory of Horticultural Science, Division of Agricultural Botany, Department of Plant \\ Resources, Faculty of Agriculture, Kyushu University, \\ Fukuoka 812-8581, Japan
}

(Received October 22, 2002 and accepted November 7, 2002)

\begin{abstract}
Self-incompatibility in Camellia japonica cultivars was compared. From the self-pollination of ten cultivars, 'Hatsu-arashi', 'Kanto-hatsuwarai', 'Aki-no-yama' and 'Fukumusume' revealed the fruit set from 5.0 to $27.0 \%$, and perfect seeds could be obtained from 'Hatsu-arashi' and 'Fukumusume'. Self- and cross-pollination showed similar values in percentages of perfect seeds and of germination. Two seedlings from self-pollination of 'Hatsu-arashi' were conducted for isozyme analysis, and were found to be derived from self-fertilization.
\end{abstract}

\section{INTRODUCTION}

Camellia japonica is a perennial woody plant, and easily propagated by cutting and grafting. As a long time, at least three or four years, is necessary from seed sowing to flowering in this species, there is little information on the inheritance of phenotypic characteristics. A self-incompatible system plays a role to preserve the genetic heterozygosity and prevents from inbreeding depression. It is another cause of the difficulty of genetic studies in this species.

Self-incompatibility systems are based upon the inherited capacity of the flowers to reject its own pollen, and have been studied in many plant species (De Nettancourt, 1977). Camellia spp. are generally known to be self-incompatible (Tanaka, 1985), but detailed investigation of the genetic control of self-incompatibility is restricted. Fuchinoue (1969) reported that Camellia sinensis has a gametophytic self-incompatible system by self- and cross-pollination. Hakoda and Matsumoto (1979) described that several cultivars bore fruits by self-pollination in Camellia sasanqua. Variation of self-incompatibility was investigated in this study for the basis of the genetic control of self-incompatibility in C. japonica.

\section{MATERIALS AND METHODS}

All the crosses of the present experiments were conducted using mature C. japonica trees cultivated in the field of University Forest of Kyushu University, Fukuoka. Eight diploid cultivars, 'Hatsu-arashi', 'Kanto-hatsuwarai', 'Aki-no-yama', 'Asahi-no-mai',

\footnotetext{
* Laboratory of Horticultural Science, Division of Agricultural Botany, Department of Plant Resources, Graduate School of Bioresource and Bioenvironmental Sciences, Kyushu University

† Corresponding author (E-mail: ozaki@farm.kyushu-u.ac.jp)
} 
'Fuku-musume', 'Kami-kakushi', 'Hana-fuuki' and 'Oniji', two diploid wild strains, Hirado Nos. 2 and 3, and two triploid cultivars, 'Kumagai' and 'Akashigata',were used in this investigation. Ten combinations (Table 1) of self-pollination and eight combinations of cross-pollination were carried out from December 29, 1997 to April 4, 1998, and from January 6 to April 16, 1999. The flowers of seed parents were emasculated one or two days before anthesis, and then pollinated with fresh pollen. All pollinated pistils were covered with paper bags for isolation. Number of normally growing fruits from three to four months after pollination was counted.

Fruits were harvested in the middle September, and the seeds were taken out from the fruits. The seeds were classified into "perfect seed" with normal embryo and "empty seed" without embryo. The perfect seeds were then soaked in $100 \mathrm{mgl}^{-1} \mathrm{GA}_{3}$ solution for 30 minutes at $25^{\circ} \mathrm{C}$ after scarification, and sown in moisted sphagnum moss. After germination, the seedlings were transplanted in pumice in plastic pots, $9 \mathrm{~cm}$ in diameter, and supplied for isozyme analysis.

Mature leaves were used for enzyme extraction. Each sample was homogenized in pre-cooled extraction buffer prepared as described by Wendel (1983). Crude enzyme extracts were absorbed onto filter paper wicks (Whatman $\# 3,11 \times 3 \mathrm{~mm}$ ) and used for electrophoresis. The detailed procedure of enzyme extraction, horizontal starch gel electrophoresis and gel staining followed the methods of Wendel (1983). Enzymes analyzed were alcohol dehydrogenase (ADH; EC 1.1.1.1), glucosephosphate isomerase (GPI; EC 5.3.1.9), isocitrate dehydrogenase (IDH; EC 1.1.1.41), phosphoglucomutase (PGM; 5.4.2.2) and shikimate dehydrogenase (SKDH; EC 1.1.1.25). Genetic basis and allozyme determination of the loci followed the results of Eguchi et al. (1991), and the new allele in $\mathrm{ADH}-2$ region, which was first identified in this study, was named a'.

\section{RESULTS}

The results of the self- and cross-pollination are represented in Table 1. Four combinations of the cross-pollination, 'Hana-fuuki' $\times$ 'Kanto-hatsuwarai', 'Hatsu-arashi' $\times$ 'Kanto-hatsuwarai', 'Kanto-hatsuwarai' $X$ 'Fuku-musume' and 'Kanto-hatsuwarai' $X$ 'Hatsu-arashi' showed 27.6 to $58.8 \%$ fruit set, while the rest combinations brought no fruit set. Most of the self-pollinated crosses resulted no fruit set, whereas 'Aki-no-yama', 'Fuku-musume', 'Hatsu-arashi' and 'Kanto-hatsuwarai' showed 5.0 to $27.0 \%$ fruit set. All the fruit from self-pollination of 'Aki-no-yama', however, dropped before maturity, and there were no perfect seeds in the fruit from 'Kanto-hatsuwarai' self-pollination. Six and eight perfect seeds were obtained from self-pollination in 'Fuku-musume' and 'Hatsu-arashi', respectively. Percentages of perfect seeds in the harvested seeds from self- and cross-pollination were the same (51.9\%), and the similar values of percentage of germination in the perfect seeds were also recognized in self- (57.1\%) and cross-pollination $(57.9 \%)$.

Most of the seedlings from self-pollination showed depressed growth, and only two seedlings from 'Hatsu-arashi' self-pollination were supplied for isozyme analysis. Among the five enzyme systems analyzed, five regions, ADH-2, GPI-2, IDH, PGM-2 and SKDH, were resolved in this study as shown in Fig. 1. Genotypes of Hatsu-arashi self-1 were the same as those of the parent 'Hatsu-arashi' in $A d h-2, G p i-2, I d h$ and $S k d h$ loci, and 
Table 1. Results of self- and cross-pollination in C. japonica

\begin{tabular}{|c|c|c|c|c|c|c|c|c|c|c|}
\hline \multicolumn{2}{|l|}{ Cross combination } & \multirow{2}{*}{$\begin{array}{l}\text { No. of } \\
\text { flowers } \\
\text { pollinated }\end{array}$} & \multirow{2}{*}{$\begin{array}{l}\text { No. of } \\
\text { fruits } \\
\text { set }\end{array}$} & \multirow{2}{*}{$(\%)$} & \multirow{2}{*}{$\begin{array}{l}\text { No. of } \\
\text { fruits } \\
\text { harvested }\end{array}$} & \multicolumn{3}{|c|}{ No. of seeds } & \multirow{2}{*}{$\begin{array}{l}\text { No. of seeds } \\
\text { germinated }\end{array}$} & \multirow{2}{*}{$(\%)$} \\
\hline Seed parents & ollen parents & & & & & Total & Perfect & Empty & & \\
\hline \multicolumn{11}{|l|}{ Self-pollination } \\
\hline Aki-no-yama & Self & 37 & 10 & $(27.0)$ & 0 & - & - & - & - & - \\
\hline Asahi-no-mai & Self & 25 & 0 & $(0)$ & - & - & - & - & - & - \\
\hline Fuku-musume & Self & 33 & 2 & $(6.1)$ & 2 & 8 & 6 & 2 & 4 & $(66.7)$ \\
\hline Hana-fuuki & Self & 20 & 0 & $(0)$ & - & - & - & - & - & - \\
\hline Hatsu-arashi & Self & 16 & 3 & (18.8) & 2 & 18 & 8 & 10 & 4 & $(50.0)$ \\
\hline Hirado No. 2 & Self & 5 & 0 & $(0)$ & - & - & - & - & - & - \\
\hline Kami-kakushi & Self & 8 & 0 & $(0)$ & - & - & - & - & - & - \\
\hline Kanto-hatsuwarai & Self & 20 & 1 & $(5.0)$ & 1 & 1 & 0 & 1 & - & - \\
\hline Akashigata (3x) & Self & 20 & 0 & $(0)$ & - & - & - & - & - & - \\
\hline Kumagai $(3 \mathrm{x})$ & Self & 27 & 0 & $(0)$ & - & - & - & - & - & - \\
\hline Total (Mean) & & 211 & 16 & $(7.6)$ & 5 & 27 & 14 & 13 & 8 & $(57.1)$ \\
\hline \multicolumn{11}{|l|}{ Cross-pollination } \\
\hline Fuku-musume & Kanto-hatsuwarai & 4 & 0 & $(0)$ & - & - & - & - & - & - \\
\hline Hana-fuuki & Kanto-hatsuwarai & 17 & 10 & $(58.8)$ & 9 & 83 & 35 & 48 & 2 & ( 5.7$)$ \\
\hline Hatsu-arashi & Kanto-hatsuwarai & 36 & 20 & $(55.6)$ & 19 & 151 & 78 & 73 & 58 & $(74.4)$ \\
\hline Hirado No. 2 & Hirado No. 3 & 12 & 0 & $(0)$ & - & - & - & - & - & - \\
\hline Hirado No. 3 & Hirado No. 2 & 19 & 0 & $(0)$ & - & - & - & - & - & - \\
\hline Kanto-hatsuwarai & Fuku-musume & 6 & 3 & $(50.0)$ & 3 & 10 & 9 & 1 & 6 & $(66.7)$ \\
\hline Kanto-hatsuwarai & Hatsu-arashi & 29 & 8 & $(27.6)$ & 7 & 26 & 18 & 8 & 15 & (83.3) \\
\hline Ooniji & Kanto-hatsuwarai & 18 & 0 & $(0)$ & - & - & - & - & - & - \\
\hline Total (Mean) & & 141 & 41 & (29.1) & 38 & 270 & 140 & 130 & 81 & $(57.9)$ \\
\hline
\end{tabular}

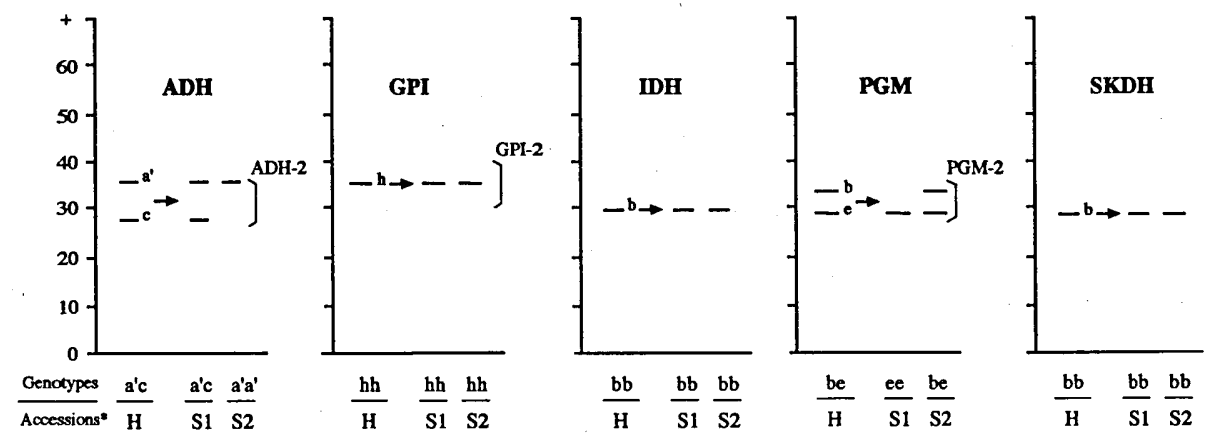

Fig. 1. Allozyme banding patterns and the genotypes in 'Hatsu-arashi' and its selfed progenies. *H: 'Hatsu-arashi', S1: Hatsu-arashi self-1, S2: Hatsu-arashi self-2. 
Hatsu-arashi self-1 had only allele "e" that was derived from 'Hatsu-arashi' in Pgm-2 locus. The genotypes of the other progeny Hatsu-arashi self-2 showed the similar results.

\section{DISCUSSION}

Perfect seeds were obtained from self-pollination of 'Hatsu-arashi' and 'Fuku-musume'. Fruit set was recognized in the self-pollination of 'Kanto-hatsuwarai' and 'Aki-no-yama', although no perfect seeds were obtained. Hagiya (1978) described that the fruit whose ovule was not fertilized dropped before one month after pollination in Camellia. Fertilization might, therefore, occur in the self-pollination of 'Kanto-hatsuwarai' and 'Aki-no-yama', and no perfect seeds were obtained in consequence of zygote degeneration during embryogenesis.

Most of the self-pollination and several cross-pollination were incompatible. Fuchinoue (1969) reported that there was a gametophytic self-incomopatibility system in tea (C. sinensis), and the incompatibility was governed by a single locus. If the similar self-incompatibility system exists in C. japonica, cross-pollination between different parents with the same self-incompatible genotypes might bring no fruit set. The selfed progenies of 'Hatsu-arashi' represented expected allozyme genotypes in each locus. It was reported that gynogenetic dihaploid plants were obtained as a result of pseudogamy in interspecific crosses between $C$. sasanqua and C. japonica (Fuchinoue, 1969). If the selfed progenies were gynogenetic dihaploids, the genotypes must be homogenic in all allozyme loci. In this study, the selfed progenies were not gynogenetic dihaploids when judged from the results of isozyme analysis, so that these may be derived from self-fertilization.

Camellia japonica is known as a protogyny species, and pistil is acceptable from a few days before anthesis (Hagiya, 1978; Hakoda and Matsumoto, 1979). The self-incompatible rejection phenomenon involves the recognition of identical gene products in pollen and style, and the time of gene action coincides with the opening of the flower (De Nettancourt, 1977). Bud pollination is known to be effective for overcoming self-incompatibility in Brassica (Brown et al., 1991) and Petunia (Cruzan, 1993).

Here in this investigation, bud pollination was carried out to examine the self-incompatibility. As Hakoda and Matsumoto (1979) indicated that the percentages of fruit set by the self-pollination on and one day before anthesis were 21.8 and $7.9 \%$, respectively, in $C$. sasanqua, bud pollination may not be effective to rise the rates of fruit set. This study proved that there are self-compatible or semi-self-compatible cultivars in C. japonica. These cultivars will play an important role to resolve the self-incompatible system and to study the inheritance of phenotypic characters for efficient cross breeding program in this species.

\section{REFERENCES}

Brown, A. P., J. Brown and A. F. Dyer 1991 'Optimal pollination conditions for seed set after a self-pollination, an intraspecific cross and an interspecific cross of marrow-stem kale (Brassica oleracea var. acepala). Euphytica, 51: 207-214

Cruzan, M. B. 1993 Analysis of pollen-style interactions in Petunia hybrida; the determination of variance in male reproductive success. Sex. Plant Reprod., 6: 275-281 
De Nettancourt, D. 1977 Incompatibility in Angiosperms. Springer-Verlag, Berlin, Heidelberg

Eguchi, T., H. Okubo, K. Fujieda and S. Uemoto 1991 Genetic divergence among intraspecific taxa of Camellia japonica L. J. Japan. Soc. Hort. Sci., 59: 803-814

Fuchinoue, Y. 1969 Studies on the Genetic Control of Self-incompatibility and pseudogamy in tea (Camellia sinensis). Ph D. Thesis, Hokkaido University, Hokkaido (In Japanese with English summary)

Hagiya, K. 1978 Breeding of Camellia. In "Encyclopedia of Camellias in Color", Vol. 2, ed. by Nippon Tsubaki Kyokai, Kodansha, Tokyo, pp. 273-291 (In Japanese. The title was tentatively translated by Y. Ozaki.)

Hakoda, N. and M. Matsumoto 1979 Cross compatibility in Camellia sasanqua and its relatives. In "Studies on the Origin and Ecological Differentiation in Camellia Species", ed. by S. Uemoto. Report of Grant-in-Aid from the Ministry of Education, Science, Sports and Culture of Japan, pp. 39-46 (In Japanese. The title was tentatively translated by Y. Ozaki.)

Tanaka, T. 1985 Studies on the Origin of Camellia vernalis. Ph D. Thesis, Kyushu University, Fukuoka (In Japanese with English summary)

Wendel, J. F. 1983 Electrophoretic analysis of genetic variation in wild and cultivated Camellia japonica L. Ph. D. Thesis, University of North Carolina, Chapel Hill 